\title{
KENYAMANAN TERMAL PADA RUANG PAMERAN TETAP DI MUSEUM NASIONAL INDONESIA - JAKARTA
}

\author{
Heru Budi Kusuma ${ }^{1}$ \\ ${ }^{1}$ Fakultas Seni Rupa dan Desain, Universitas Tarumanagara Jakarta \\ Email: heruk@fsrd.untar.ac.id
}

\begin{abstract}
ABSTRAK
Pada bulan Oktober dan November 2013, pengelola Museum Nasional melakukan "Kajian - Monitoring dan Evaluasi - Tata Pameran Museum Nasional. Ada 20 aspek yang dikaji, dua diantaranya adalah tentang "Suasana Ruang Pameran dan Kondisi Umum Museum Nasional”. Metode kajian yang dilakukan menggunakan Metode Kuantitaf dengan teknik analisis menggunakan pendekatan model CIPO (Context, Input, Process, Output). Adapun hasil akhirnya menyimpulkan bahwa, kajian mengenai "Suasana Ruang Pameran" menghasilkan skor 2,41 yang berarti Kurang Baik, dan kajian terhadap "Kondisi Umum Museum Nasional” menghasilkan skor 2,9 yang berarti Cukup Baik. Berdasar dari hasil kajian tersebut,peneliti berupaya melakukan Penelitian Kualitatif guna menganalisis “Kenyamanan Termal pada Ruang Pameran Tetap di Museum Nasional Indonesia”. Setiap ruang pameran pada museum pasti membutuhkan penghawaan buatan untuk pengkondisian udara di dalam ruang pameran. Suhu udara yang diatur, kecepatan daya semburnya, dan kelembaban udara dalam ruang merupakan aspek penting di ruang pameran karena berbagai masalah akan timbul ketika kualitas udara dan tingkat kelembaban di tempat tersebut tidak memenuhi standard, karena kondisi suhu dan kelembaban yang tidak sesuai standard akan mempengaruhi materi koleksi dan kenyamanan termal terhadap pengunjungnya. Kajian terhadap "Kenyamanan Termal pada Ruang Pameran Tetap" menggunakan Metode Kualitatif. Variabel data yang dianalisis dalam penelitian ini adalah:hasil angket dari penelitian pengelola museum terhadap "Suasana Ruang Pameran dan Kondisi Umum Museum Nasional”, data referensi tentang Standar Kenyamanan Termal dalam ruangan, dan pengambilan data empiris di ruang pameran tetap Museum Nasional dengan menggunakan alat ukur Thermo Hygrometer, Laser Thermometer dan Laser Length Meter. Hasil perekaman dan pengukuran dianalisis dan diverifikasi dengan menggunakan metode Triangulasi. Sebagai simpulan dari penelitian yang dilakukan, diketahui bahwa kondisi suhu udara dan tingkat kelembaban udara dalam ruang pameran tetap pada umumnya berada pada kondisi "Hangat Nyaman" dan kondisi suhu udara dan tingkat kelembaban di area sekitar void escalator dalam kondisi "Nyaman Optimal".
\end{abstract}

Kata kunci : suhu udara, tingkat kelembaban udara, kenyamanan termal

\section{PENDAHULUAN}

Museum adalah tempat dipamerkannya benda tangible (fosil, artefak) dan intangible (nilai, tradisi, norma). Peran dan fungsi utama museum adalah sebagai lembaga edukatif. Tantangannya bagaimana visi misi museum sejalan dengan harapan masyarakat. Pada umumnya museum-museum di Indonesia tak mampu menyajikan model edukasi atau alih pengetahuan secara menarik, informatif, dan atraktif kepada masyarakat (Svarijati, 2009).

Desain adalah suatu sistem yang berlaku untuk segala macam jenis perancangan dimana titik beratnya adalah melihat sesuatu persoalan tidak secara terpisah atau tersendiri, melainkan sebagai suatu kesatuan dimana suatu masalah dengan lainnya saling kait-mengait. Kerangka desain pada hakekatnya mencakup tiga komponen yang satu sama lain saling terkait, yaitu context, need dan form (Suptandar, 1995).

Desain adalah bidang yang memiliki satuan keilmuan yang lebih terbuka dan dinamis, dengan ukuran-ukuran yang lebih relatif. Penelitian desain - sebagaimana penelitian pada umumnya bertujuan menghasilkan pengetahuan. Akan tetapi, di dalam penelitian desain, pengetahuan itu diperoleh melalui dua model epistemologi. Pertama, penelitian murni, yang keluarannya adalah pengetahuan itu sendiri. Kedua, penelitian terapan atau penelitian desain, yang keluarannya 
adalah produk atau obyek, yang di dalamnya secara implisit terkandung pengetahuan tertentu. Berdasarkan dua keluaran itu, dapat dikatakan, bahwa penelitian desain dapat mempunyai dua tujuan yang berbeda, yaitu memahami (understanding, encoding) dan menciptakan (creating, encoding) (Piliang, 2010).

Kondisi termal dalam bangunan (suhu, kelembaban, kecepatan angin dan radiasi matahari) mempengaruhi kondisi termal didalam bangunan, yang pada akhirnya dapat mempengaruhi kondisi materi koleksi di ruang pameran. Kondisi termal juga mempengaruhi kenyamanan pengunjung selama berkativitas menikmati materi koleksi di ruang pameran. Cepat atau lambatnya, kondisi suhu udara dan kelembaban udara dalam ruang pameran tetap tidak hanya mempengaruhi kenyaman termal bagi pengunjung, tapi juga dapat berkontribusi terhadap kerusakan bahan koleksi yang dipamerkan. Kenyamanan temperatur udara dalam ruangan untuk daerah tropis dibagi menjadi

- Sejuk nyaman, antara temperatur efektif $20,5^{0}-22,8^{0}$ Celcius;

- Nyaman optimal, antara temperatur efektif $22,8^{0}-25,8^{0}$ Celcius;

- Hangat nyaman, antara temperatur efektif 25,8 - 27, $1^{0}$ Celcius (SNI 03-6572-2001).

Standard ASHRAE yang telah diakreditasi oleh American National Standards Institute (ANSI), menyatakan pada standard 55 - 56 kondisi temperatur dan tingkat kelembaban udara yang nyaman dalam ruangan adalah sebagai berikut:

- Kondisi temperatur, $23^{0}-25^{0}$ Celcius;

- Ratio maksimum perubahan : $1.1^{0}-2.2^{0}$ Celcius/jam

- Kondisi Kelembaban udara : $60 \%$;

- Ratio maksimum perubahan : $10 \%-20 \%$ per jam;

- Kecepatan udara didalam ruang 0.05-0,23 meter/detik, (Fred Lawson, 1981)

Metode kajian yang dilakukan menggunakan Metode Kuantitaf dengan teknik analisis menggunakan pendekatan model CIPO (Context, Input, Process, Output). Adapun hasil akhirnya menyimpulkan bahwa, kajian mengenai "Suasana Ruang Pameran" menghasilkan skor 2,41 yang berarti Kurang Baik, dan kajian terhadap "Kondisi Umum Museum Nasional" menghasilkan skor 2,9 yang berarti Cukup Baik. Berdasar dari hasil kajian tersebut,peneliti berupaya melakukan Penelitian Kualitatif guna menganalisis "Kenyamanan Termal pada Ruang Pameran Tetap di Museum Nasional Indonesia", dimana kenyamanan termal merupakan salah satu faktor yang dapat mempengaruhi suasana dalam ruang pameran tetap. 


\begin{tabular}{|c|c|c|c|}
\hline $\begin{array}{c}\text { pertanyaan } \\
\text { no }\end{array}$ & Keterangan & $\begin{array}{c}\text { Mean teoretis } \\
(\mu)\end{array}$ & $\begin{array}{c}\text { Persentase } \\
(\%)\end{array}$ \\
\hline 1 & $\begin{array}{l}\text { Frekuensi kunjungan Ke } \\
\text { Museum Nasional }\end{array}$ & 2,53 & $50,55 \%$ \\
\hline 2 & $\begin{array}{l}\text { Frekuensi kunjungan ke } \\
\text { Museum Dalam Negeri }\end{array}$ & 2,48 & $49,51 \%$ \\
\hline 3 & $\begin{array}{l}\text { Frekuensi kunjungan ke } \\
\text { Museum Luar Negeri }\end{array}$ & 1,70 & $33,96 \%$ \\
\hline 4 & 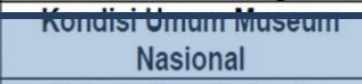 & 2,90 & $58,02 \%$ \\
\hline 5 & $\begin{array}{l}\text { Ketertanikan Temauap } \\
\text { Koleksi Pamer }\end{array}$ & 3,47 & $69,40 \%$ \\
\hline 6 & $\begin{array}{l}\text { Kepadatan koleksi di } \\
\text { Ruang Pamer }\end{array}$ & 2,82 & $56,43 \%$ \\
\hline 7 & $\begin{array}{l}\text { Kepadatan koleksi di } \\
\text { Ruang Pamer }\end{array}$ & 2,35 & $47,03 \%$ \\
\hline 8 & $\begin{array}{c}\text { Penataan Koleksi Secara } \\
\text { Umum }\end{array}$ & 2,47 & $49,34 \%$ \\
\hline - & Trussanta Rutung Pamer-1 & 2,44 & $40,00 \%$ \\
\hline & Perawatan dan Kebersihan & 206 & \\
\hline 10 & Koleksi & 2,0 & $-0,210$ \\
\hline 11 & Tata cahaya eksterior & 2,56 & $51,15 \%$ \\
\hline 12 & Warna & 2,48 & $49,53 \%$ \\
\hline 13 & Penempatan Grafis & 2,86 & $57,24 \%$ \\
\hline 14 & Informasi label koleksi & 2,48 & $49,69 \%$ \\
\hline 15 & Informasi Penunjuk Arah & 2,45 & $49,01 \%$ \\
\hline 16 & Bentuk Vitrin & 2,57 & $51,35 \%$ \\
\hline 17 & Ukuran Vitrin dan Koleksi & 2,50 & $50,00 \%$ \\
\hline 18 & $\begin{array}{c}\text { Penataan koleksi dalam } \\
\text { Vitrin } \\
\end{array}$ & 2,50 & $50,00 \%$ \\
\hline 19 & Tata cahaya Interior & 2,51 & $50,10 \%$ \\
\hline 20 & Sajian Audio-Visual & 2,45 & $48,98 \%$ \\
\hline \multicolumn{2}{|r|}{ Rata-rata } & 2,44 & $48,79 \%$ \\
\hline \multicolumn{2}{|r|}{ Mean Anisis } & 64,28 & $64,28 \%$ \\
\hline
\end{tabular}

Gambar 1. Hasil Kajian Tata Pamer (Perangkat Pameran) Museum Nasional Tahun 2013

Berdasarkan data literatur mengenai Standar suhu udara dan kelembaban udara dalam ruang, maka masalah dalam penelitian ini dapat dirumuskan sebagai berikut:

a. Berapakah suhu udara rata- rata didalam ruang pameran tetap Museum Nasional Indonesia ?

b. Berapakah tingkat kelembaban udara rata-rata didalam ruang pameran tetap Museum Nasional Indonesia?

c. Bagaimana kondisi termal secara umum didalam ruang pameran tetap Museum Nasional Indonesia? 


\section{METODE PENELITIAN}

Penelitian yang dilakukan guna mengukur tingkat kenyamanan diruang pameran tetap Museum Nasional ini menggunakan Metode Penelitian Kualitatif. Metode ini disebut juga sebagai metode artistik, karena proses penelitian lebih bersifat seni. Disebut juga sebagai metode interpretive, karena data hasil penelitian lebih berkenaan dengan interprestasi terhadap data yang ditemukan di lapangan. Selain itu, metode penelitian kualitatif sering disebut metode penelitian naturalistik karena penelitiannya dilakukan pada kondisi yang alamiah (natural setting), Disebut juga metode etnographi, karena pada awalnya metode ini lebih banyak digunakan untuk penelitian bidang antropologi budaya (Sugiyono, 2006).

Dalam pandangan penelitian kualitatif, gejala bersifat holistik (menyeluruh, tidak dapat dipisah-pisahkan), sehingga variabel penelitian yang mencakup aspek tempat (place), pelaku (actor), dan aktivitas (activity) dipandang sebagai situasi sosial yang menyeluruh dan berinteraksi secara sinergi. Untuk mempertajam masalah, maka dalam peneltian kualitatif perlu membatasi masalah yang disebut dengan fokus, yang berisi pokok masalah yang masih bersifat umum. Masalah dalam penelitian kualitatif, dikatakan feasible apabila terdapat berbagai sumber daya untuk memecahkan masalah tersebut (Sugiyono, 2006).

Teknik pengambilan data menggunakan dua teknik sampling, yaitu purposive sampling, yaitu teknik pengambilan sampel sumber data dengan pertimbangan tertentu, dimana dalam penelitian ini memilih area pameran tetap lantai 2 , dengan Story Line-nya adalah Ilmu Pengetahuan, Teknologi dan Ekonomi. Kebutuhan data yang diperlukan adalah: mengetahui fungsi ruangan, mengetahui volume ruangan (Panjang $\mathrm{x}$ Lebar $\mathrm{x}$ Tinggi ruangan), dan mengetahui ukuran bukaan (opening) yang dibutuhkan untuk sirkulasi udara dalam ruangan. Dalam melaksanakan pengambilan data untuk mengukur temperature ruangan dan tingkat kelembaban udara dalam ruang pameran tetap, ditentukan 17 titik pengukuran yang sekiranya dapat mewakili tiap sisi ruangan.

Alat atau instrumen yang digunakan untuk mengambil data suhu udara dan tingkat kelembaban udara dalam ruang pameran tetap Museum Nasional Indonesia adalah: Hygrometer, Infra Red Thermometer, Laser Length Meter, dan Kartu Pencatatan Data. Hygrometer adalah instrumen atau alat yang digunakan untuk mengambil data kelembaban udara dalam ruang pameran tetap yang dapat menunjukkan kelembaban relatif (persentase kelembaban di udara), kelembaban mutlak (jumlah kelembaban) atau keduanya. Infra Red Thermometer perangkat atau alat untuk mendeteksi temperatur atau suhu secara optik selama objek diamati, paparan radiasi sinar infra red pada obyek yang diukur selanjutnya dilayar akan menampilkan angka digital hasil pengukuran suhu. Laser Length Meter atau meteran laser digital ialah alat pengukur jarak yang menggunakan teknologi laser atau dalam bahasa Inggris dikenal dengan digital laser distance, alat ini dapat mengukur jarak dengan efektif menggunakan laser. Kartu pencatatan data merupakan perangkat yang digunakan sebagai bank data hasil pengukuran dilokasi penelitian. Pencatatan merupakan kegiatan atau proses pendokumentasian suatu aktifitas dalam bentuk tulisan diatas kertas, file komputer, dan lain-lain dengan ilustrasi tulisan, grafik, gambar, dan suara. Semua kegiatan pokok dalam proses pengambilan data penelitian di ruang pameran tetap dicatat. 


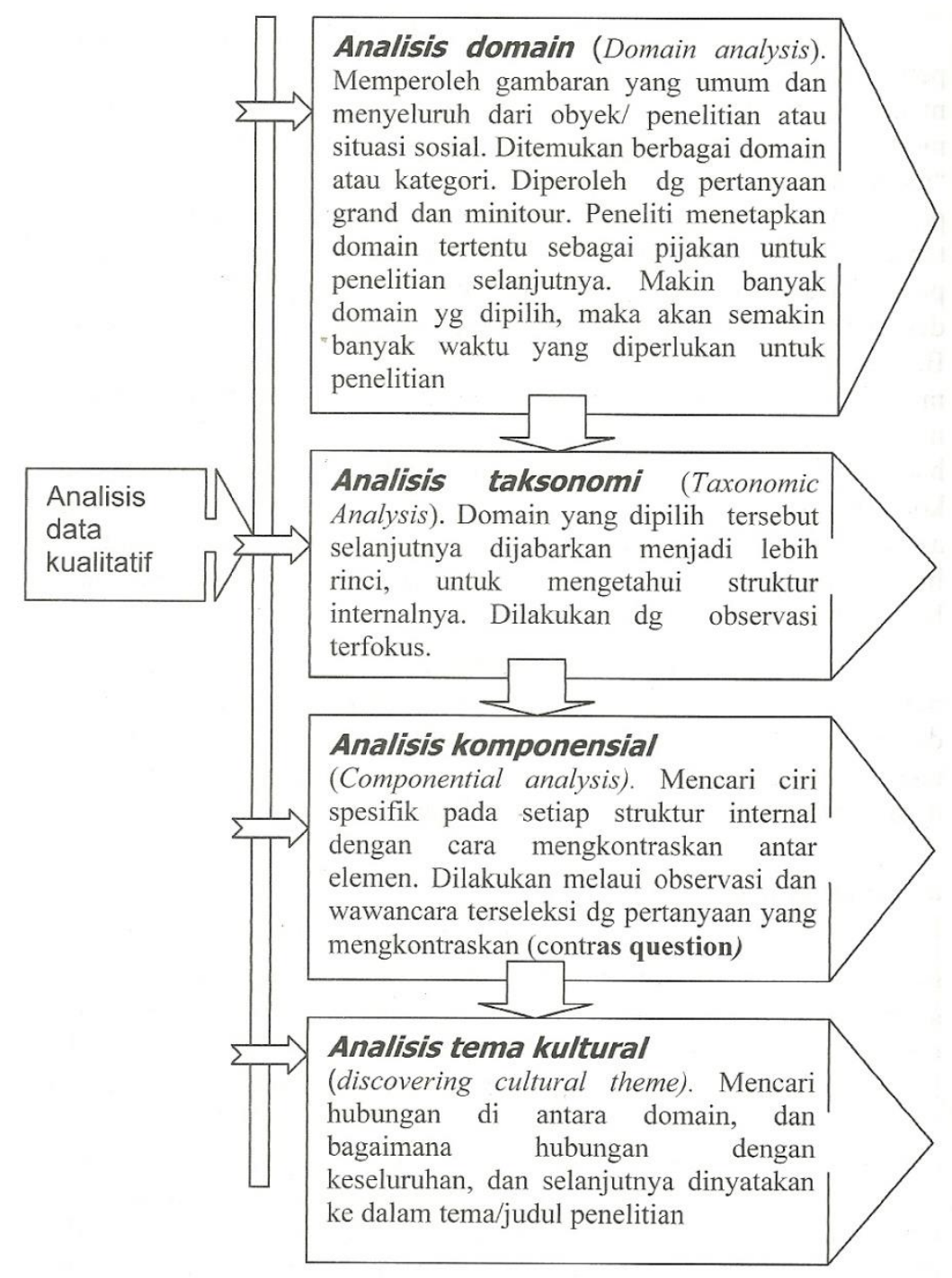

Diagram 1: Macam Analisis Data Kualitatif (Spradley, dalam Sugiyono, 2006)

\section{HASIL DAN PEMBAHASAN}

Penelitian ini mengambil objek penelitian di Museum Nasional Indonesia, yang berlokasi di jalan Medan Merdeka Barat No. 12, Jakarta Pusat. Museum kini terdiri dari dua buah bangunan. Bangunan pertama, atau Gedung "A" adalah bangunan bekas Bataviaasch Genootschap van Kunsten en Westenschappen dulu, dimana terdapat ruang penyimpanan koleksi dan sebagian besar pameran permanen. Bangunan kedua yaitu Gedung "B" adalah bangunan baru yang dibangun pada tahun 2003 dan sekarang menjadi kantor museum, empat lantai untuk pameran tetap dan satu lantai untuk ruang pameran temporer. Ruang Pameran Tetap di Gedung "B" terdiri dari empat tema yaitu Manusia dan Lingkungan, Ilmu Pengetahuan, Teknologi dan Eknonomi, Organisasi Sosial dan Pola Pemukiman dan Khasanah Emas dan Keramik. Penilitian dipusatkan pada ruang pameran tetap dilantai 2 dengan tema Ilmu Pengetahuan, Pengetahuan dan Ekonomi. 


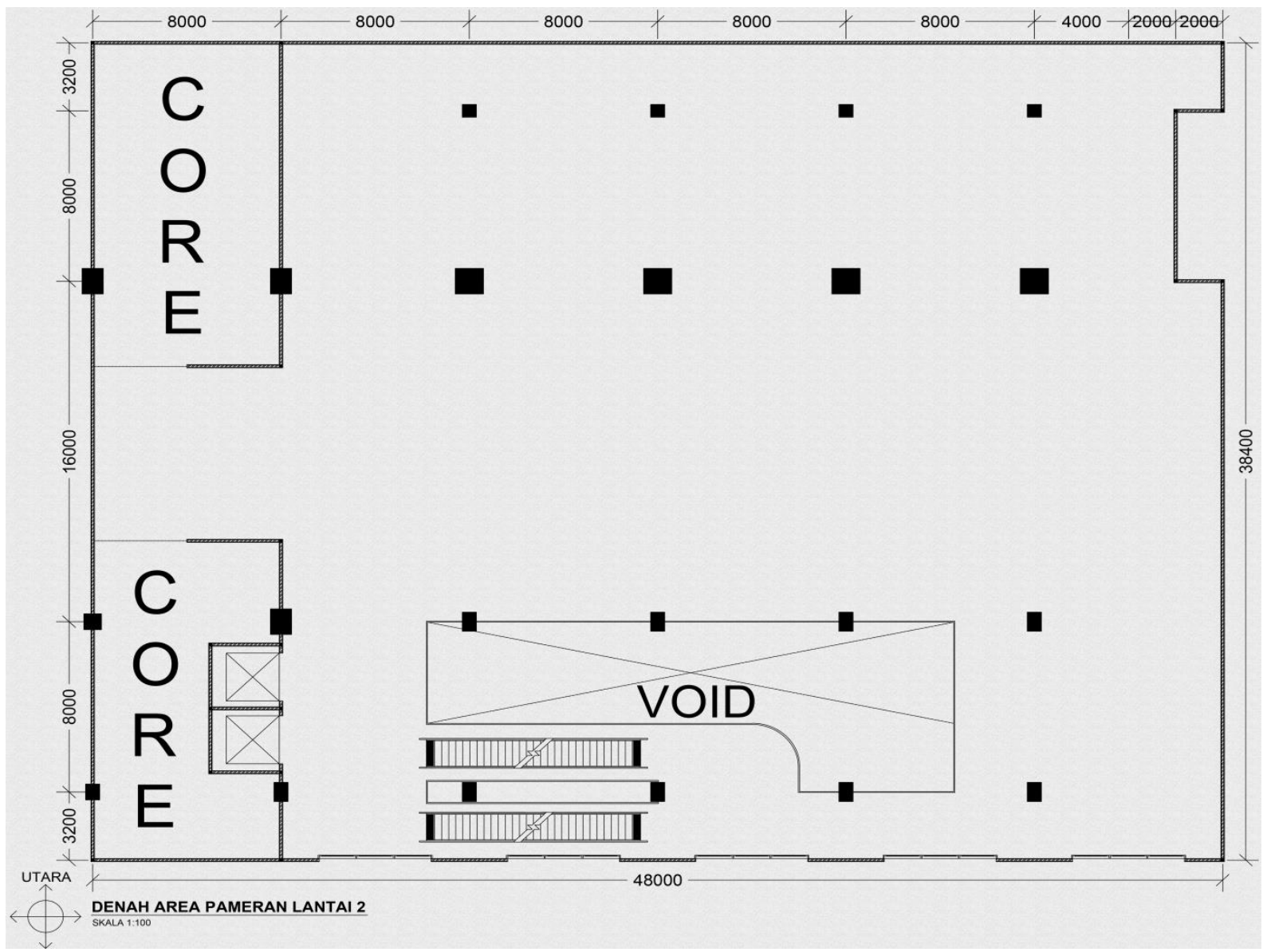

Gambar 2: Denah Kosong Ruang Pameran Tetap Lantai 2 Gedung 'B'

Luas lantai 2 di gedung 'B' adalah 38,4 m x $48 \mathrm{~m}=1.843,2 \mathrm{~m}^{2}$, dengan luas area yang digunakan untuk ruang pameran tetap adalah $27,2 \mathrm{~m} \mathrm{x} 40 \mathrm{~m}=1.088 \mathrm{~m}^{2}$ dan volume ruang pameran tetap $1.088 \mathrm{~m} 2 \times 2,7 \mathrm{~m}=29,397 \mathrm{~m}^{3}$. Dalam SNI 03-6572-2001 mensyaratkan jumlah bukaan ventilasi tidak kurang dari 5\% terhadap luas lantai ruangan yang membutuhkan ventilasi, sehingga total bukaan yang dibutuhkan dalam ruang pameran tetap lantai 2 adalah $1.843,2 \mathrm{~m} 2 \mathrm{x}$ $5 \%=92,16 \mathrm{~m}^{2}$. Total bukaan untuk sirkulasi udara sudah memadai, dengan membuat partisi atau penyekat ruang yang tidak solid, sehingga udara masih dapat melewati sisi kanan, sisi kiri, dan bagian atas partisi atau furniture yang ada diruang pameran. Ditambah lagi dengan adanya void escalator, ini sangat membantu sirkulasi udara dapat mengalir secara vertical. Sistem sirkulasi udara dalam ruang pameran tetap menggunakan AC sentral, dan menggunakan unit suply dan return air berukuran $60 \times 60 \mathrm{~cm}$, maka dibutuhkan 128 titik supply dan return air yang harus terpasang diruang pameran tetap lantai 2 . 


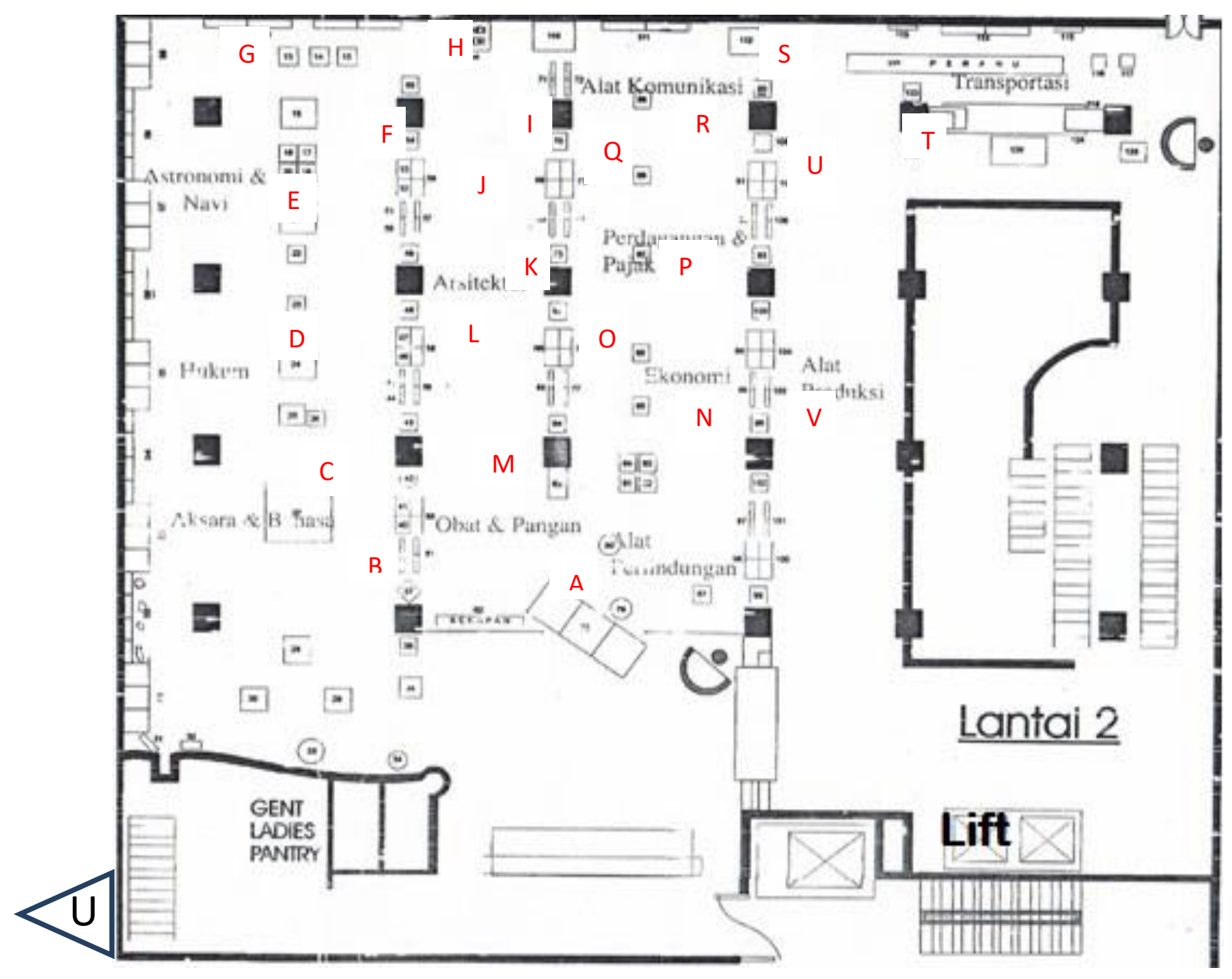

Gambar 3: Denah Ruang Pameran Tetap Gedung B Lantai 2

Pengaruh orientasi bangunan Museum Nasional Indonesia khususnya Gedung "B", sangat mempengaruhi kualitas kenyamanan termal didalam ruang pameran tetapnya yang mana sisi Timur dan sisi Utara bangunan terpapar radiasi matahari langsung. Orientasi bangunan yang menghadap Timur dengan potensial view menghadap jalan protokol yaitu jalan Medan Merdeka Barat dan orientasi bangunan sisi Utara yang bersebelahan dengan jalan Museum, perlu penyikapan khusus untuk mengantisipasi pengaruh sinar matahari yang berlebihan agar dapat mencapai zona nyaman didalam ruangan dapat dicapai. Selain intensitas sinar matahari yang masuk melalui sisi Timur dan sisi Utara bangunan, orientasi juga harus dapat memanfaatkan arah bangunan yang ideal terhadap arah angin, agar dapat memanfaatkan energi angin yang ada pada lokasi bangunan secara optimal untuk mendapatkan zona nyaman secara termal didalam bangunan. Penyikapan untuk melindungi fisik bangunan dari paparan radiasi sinar matahari secara langsung, dapat dilakukan dengan menanam tumbuhan berbatang keras dan besar di sisi Timur dan disisi Utara Gedung 'B' Museum Nasional Indonesia. Tumbuhan besar dengan daun yang lebat dan rimbun dapat mempengaruhi kondisi termal disekitar bangunan, selanjutnya berpotensi dapat memberikan zona nyaman secara termal didalam gedung. 


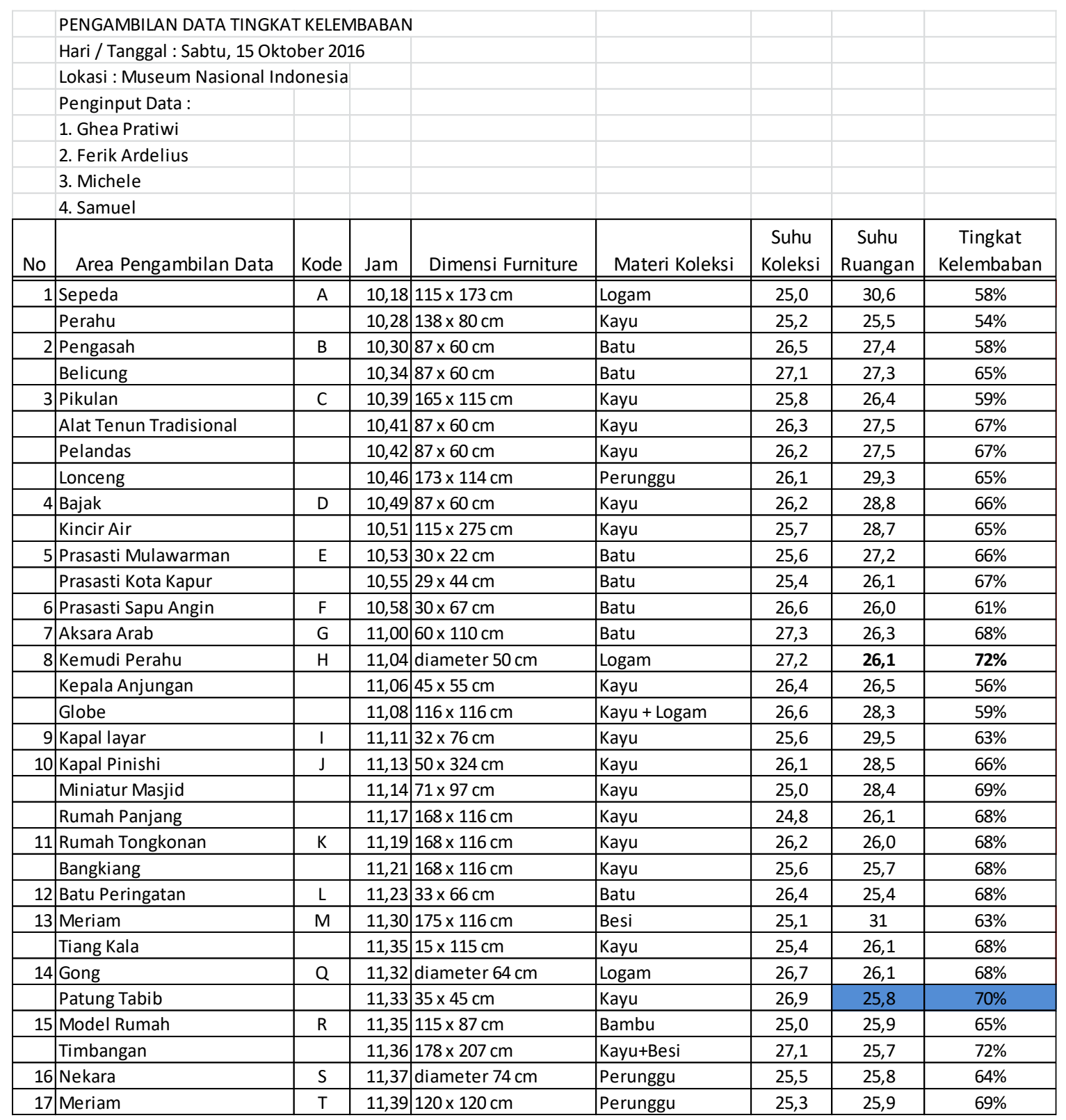

Gambar 4. Hasil Pengukuran suhu Udara dan Tingkat Kelembababn Udara dalam Ruang Pameran Tetap

Dari data pengukuran suhu udara dalam ruangan, tingkat kelembaban udara dalam ruangan, dan suhu benda materi koleksi yang ada disekitar area pengukuran dapat dibahas sebagai berikut:

\section{Area Materi Koleksi Disisi Utara Ruang Pameran Tetap}

Area materi koleksi yang berada disisi Utara adalah area pengukuran yang ditandai dengan notasi area "C", "D", "E", dan "G". Area "C" berisi materi koleksi dari bahan kayu dan perunggu, disini tercatat suhu udara $26,4^{0}-29,3^{\circ} \mathrm{C}$ dengan tingkat kelembaban udara 59\% $67 \%$ RH. Area " $D$ " berisi materi koleksi dari bahan kayu, disini tercatat suhu udara $28,7^{0}-28,8^{0}$ $\mathrm{C}$ dengan tingkat kelembaban udara $65 \%-66 \%$ RH. Area "E" berisi materi koleksi dari bahan batu, disini tercatat suhu udara $26,1^{0}-27,2^{0} \mathrm{C}$ dengan tingkat kelembaban udara $66 \%-67 \% \mathrm{RH}$. Area " $\mathrm{G}$ " berisi materi koleksi dari bahan batu, disini tercatat suhu udara $26,3^{\circ} \mathrm{C}$ dengan tingkat kelembaban udara 68\% RH. Sebagai simpulan sementara kondisi termal disisi Utara ruang 
pameran tetap tercatat suhu udara berkisar $26,1^{0}-28,8^{0} \mathrm{C}$ dan tingkat kelembaban udara berkisar 59\% - 68\% adalah kondisi termal kategori "Hangat Nyaman".

\begin{tabular}{|c|c|c|}
\hline & Temperetur Efektif (TE) & Kelembaban (RH) \\
\hline $\begin{array}{l}\text { - Sejuk Nyaman } \\
\text { Ambang atas } \\
\text { - Nyaman Optimal } \\
\text { Ambang atas } \\
\text { - Hangat Nyaman } \\
\text { Ambang atas }\end{array}$ & $\begin{array}{c}20,5^{\circ} \mathrm{C}-22,8^{\circ} \mathrm{C} \\
24^{\circ} \mathrm{C} \\
22,8^{\circ} \mathrm{C}-25,8^{\circ} \mathrm{C} \\
28^{\circ} \mathrm{C} \\
25,8 \mathrm{C}-27,1^{\circ} \mathrm{C} \\
31^{\circ} \mathrm{C}\end{array}$ & $\begin{array}{l}50 \% \\
80 \% \\
70 \% \\
60 \%\end{array}$ \\
\hline
\end{tabular}

Gambar 5. Standard Kenyamanan Termal menurut SNI 03-6572-2001

\section{Area Materi Koleksi Disisi Timur Ruang Pameran Tetap}

Area materi koleksi yang berada disisi Timur adalah area pengukuran yang ditandai dengan notasi area "G", "H", "I", dan "S". Area "G" berisi materi koleksi dari bahan batu, disini tercatat suhu udara 26,30 C dengan tingkat kelembaban udara $68 \%$ RH. Area "H" berisi materi koleksi dari bahan kayu dan logam, disini tercatat suhu udara $26,1^{\circ}-28,3^{\circ} \mathrm{C}$ dengan tingkat kelembaban udara $59 \%$ - 72\% RH. Area "I" berisi materi koleksi dari bahan kayu, disini tercatat suhu udara $29,5^{\circ} \mathrm{C}$ dengan tingkat kelembaban udara $63 \% \mathrm{RH}$. Area "S" berisi materi koleksi dari bahan perunggu, disini tercatat suhu udara $25,8^{\circ} \mathrm{C}$ dengan tingkat kelembaban udara 64\% RH. Sebagai simpulan sementara kondisi termal disisi Timur ruang pameran tetap tercatat suhu udara berkisar $26,1^{\circ}-29,5^{\circ} \mathrm{C}$ dan tingkat kelembaban udara berkisar 59\% $72 \%$ adalah kondisi termal kategori "Hangat Nyaman".

\section{Area Materi Koleksi Ditengah Ruang Pameran Tetap}

Area materi koleksi yang berada ditengah ruangan adalah area pengukuran yang ditandai dengan notasi area "K", "L", dan "M". Area "K" berisi materi koleksi dari bahan kayu, disini tercatat suhu udara $25,7^{0}$ $26^{0} \mathrm{C}$ dengan tingkat kelembaban udara $68 \%$ RH. Area "L" berisi materi koleksi dari bahan batu, disini tercatat suhu udara $25,4^{\circ} \mathrm{C}$ dengan tingkat kelembaban udara $68 \% \mathrm{RH}$. Area "M" berisi materi koleksi dari bahan besi dan kayu, disini tercatat suhu udara $26^{0}-31^{0} \mathrm{C}$ dengan tingkat kelembaban udara $63 \%$ $68 \%$ RH. Sebagai simpulan sementara kondisi termal ditengah ruang pameran tetap tercatat suhu udara berkisar $25,7^{0}-31^{0} \mathrm{C}$ dan tingkat kelembaban udara berkisar $63 \%$ - $68 \%$ adalah kondisi termal kategori "Hangat Nyaman".

\section{Area Materi Koleksi di Area Void Escalator}

Area materi koleksi yang berada ditengah ruangan adalah area pengukuran yang ditandai dengan notasi area " $\mathrm{T}$ " berisi materi koleksi dari bahan perunggu, disini tercatat suhu udara $25,9^{0} \mathrm{C}$ dengan tingkat kelembaban udara 69\% RH. Sebagai simpulan sementara kondisi termal di area void escalator ruang pameran tetap tercatat suhu udara berkisar $25,9^{0}$ dan tingkat kelembaban udara 69\% adalah kondisi termal kategori "Nyaman Optimal". 


\section{KESIMPULAN DAN SARAN Kesimpulan}

Orientasi bangunan Museum Nasional Indonesia menghadap Timur, menghadap jalan Medan Merdeka Barat, dan sisi Timur bangunan bersebelahan dengan jalan Museum. Pengaruh orientasi bangunan Museum Nasional Indonesia khususnya Gedung "B" ini, sangat mempengaruhi kualitas kenyamanan termal didalam ruang pameran tetapnya yang mana sisi Timur dan sisi Utara bangunan terpapar radiasi matahari langsung.

Luas lantai 2 di gedung ' $\mathrm{B}$ ' adalah $1.824 \mathrm{~m}^{2}$ dengan luas area yang digunakan untuk ruang pameran tetap adalah $900 \mathrm{~m}^{2}$ dan volume ruang pameran tetap $2.500 \mathrm{~m}^{3}$.

Area materi koleksi yang berada disisi Timur adalah area pengukuran yang ditandai dengan notasi area "G", "H", "I", dan "S". Area "G" berisi materi koleksi dari bahan batu, disini tercatat suhu udara $26,3^{\circ} \mathrm{C}$ dengan tingkat kelembaban udara $68 \%$ RH. Area " $\mathrm{H}$ " berisi materi koleksi dari bahan kayu dan logam, disini tercatat suhu udara $26,1^{\circ}-28,3^{\circ} \mathrm{C}$ dengan tingkat kelembaban udara 59\% - 72\% RH. Area "I" berisi materi koleksi dari bahan kayu, disini tercatat suhu udara $29,5^{\circ} \mathrm{C}$ dengan tingkat kelembaban udara $63 \% \mathrm{RH}$. Area " $\mathrm{S}$ " berisi materi koleksi dari bahan perunggu, disini tercatat suhu udara $25,8^{\circ} \mathrm{C}$ dengan tingkat kelembaban udara $64 \% \mathrm{RH}$. Sebagai simpulan sementara kondisi termal disisi Timur ruang pameran tetap tercatat suhu udara berkisar $26,1^{0}-29,5^{\circ} \mathrm{C}$ dan tingkat kelembaban udara berkisar 59\% - 72\% adalah kondisi termal kategori "Hangat Nyaman".

Area materi koleksi yang berada ditengah ruangan adalah area pengukuran yang ditandai dengan notasi area "K", "L", dan "M". Area "K" berisi materi koleksi dari bahan kayu, disini tercatat suhu udara $25,7^{0}-26^{0} \mathrm{C}$ dengan tingkat kelembaban udara $68 \% \mathrm{RH}$. Area "L" berisi materi koleksi dari bahan batu, disini tercatat suhu udara $25,4^{0} \mathrm{C}$ dengan tingkat kelembaban udara $68 \%$ RH. Area "M" berisi materi koleksi dari bahan besi dan kayu, disini tercatat suhu udara $26^{0}-31^{0}$ $\mathrm{C}$ dengan tingkat kelembaban udara 63\% - 68\% RH. Sebagai simpulan sementara kondisi termal ditengah ruang pameran tetap tercatat suhu udara berkisar $25,7^{0}-31^{0} \mathrm{C}$ dan tingkat kelembaban udara berkisar $63 \%$ - 68\% adalah kondisi termal kategori "Hangat Nyaman".

Area materi koleksi yang berada ditengah ruangan adalah area pengukuran yang ditandai dengan notasi area " $\mathrm{T}$ " berisi materi koleksi dari bahan perunggu, disini tercatat suhu udara $25,9^{0} \mathrm{C}$ dengan tingkat kelembaban udara 69\% RH. Sebagai simpulan sementara kondisi termal di area void escalator ruang pameran tetap tercatat suhu udara berkisar $25,9^{0}$ dan tingkat kelembaban udara 69\% adalah kondisi termal kategori "Nyaman Optimal".

Sebagai simpulan kondisi termal di ruang pameran tetap tercatat suhu udara rata-rata adalah $27^{0}$ $\mathrm{C}$ dan tingkat kelembaban udara rata-rata adalah $65 \% \mathrm{RH}$. Kondisi termal dalam ruang pameran tetap adalah kategori "Hangat Nyaman". Kondisi ideal dari hasil pengukuran adalah pada posisi Patung Tabib (titik Q) yang suhu udara dalam ruangan tercatat $25,8^{\circ} \mathrm{C}$ dan tingkat kelembaban udara dalam ruangannya tercatat $70 \% \mathrm{RH}$. Kondisi ruang pameran tetap dengan ventilasi udara yang ideal ditunjukan pada lokasi di area void escalator, yang tercatat suhu udara ruangannya 25,90 $\mathrm{C}$ dan tingkat kelembaban udaranya $69 \% \mathrm{RH}$, kondisi termal seperti ini masuk dalam kategori "Nyaman Optimal".

\section{Saran}

Orientasi bangunan yang menghadap Timur ke jalan Medan Merdeka Barat dan sisi Utara bangunan yang bersebelahan dengan jalan Museum, perlu disikapi dengan membuat tabir surya 
untuk melindungi fisik bangunan dari paparan radiasi sinar matahari secara langsung, dengan cara menanam tumbuhan berbatang keras dan besar di sisi Timur dan disisi Utara Gedung 'B' Museum Nasional Indonesia. Tumbuhan besar dengan daun yang lebat dan rimbun dapat mempengaruhi kondisi termal disekitar bangunan, selanjutnya berpotensi dapat memberikan zona nyaman secara termal didalam gedung.

Jumlah bukaan ventilasi tidak kurang dari $5 \%$ dari $900 \mathrm{~m}^{2}$ luas lantai ruangan yang membutuhkan ventilasi, sehingga total bukaan yang dibutuhkan dalam ruang pameran tetap lantai 2 adalah $45 \mathrm{~m}^{2}$. Sistem sirkulasi udara dalam ruang pameran tetap menggunakan AC sentral, dan menggunakan unit suply dan return air berukuran 60 x $60 \mathrm{~cm}$, maka dibutuhkan 128 titik supply dan return air yang harus terpasang diruang pameran tetap lantai 2. Void yang menghubungkan lantai 1 hingga lantai 3 secara vertikal sangat dibutuhkan untuk mengalirkan udara dalam ruang pameran tetap.

Kondisi suhu udara dan tingkat kelembaban udara dalam ruang pameran tetap yang pada umumnya berada pada kondisi "Hangat Nyaman" dan kondisi suhu udara dan tingkat kelembaban di area sekitar void escalator yang dalam kondisi "Nyaman Optimal", keduanya harus mempunyai kecepatan udara yang sama. Kondisi ruang dalam pameran tetap akan terasa nyaman jika udara mengalir pada kecepatan 0,05-0,23 meter/detik, sehingga udara mengalir secara perlahan dan angin terasa sepoi-sepoi dengan demikian diharapkan kondisi udara dalam ruangan dapat mengalir dengan baik dan kenyamanan termal dapat terkendali pada kondisi "Nyaman Optimal". Untuk mengetahui rata-rata kecepatan angin dalam ruang pameran tetap, perlu dilakukan penelitian lanjutan.

\section{Ucapan Terima Kasih}

Penulis pada kesempatan ini menyampaikan ucapan terima kasih kepada pihak-pihak yang telah memberikan izin untuk melakukan penelitian di Museum Nasional Jakarta sebagai objek penelitian. Ucapan terima kasih untuk rekan-rekan dosen Fakultas Seni Rupa dan Desain Universitas Tarumanagara yang terlibat dalam penelitian ini. Peneliti juga mengucapkan terima kasih kepada mahasiswa Fakultas Seni Rupa dan Desain Universitas Tarumanagara yang terlibat dalam penelitian ini.

\section{REFERENSI}

Lawson, F. (1981). Confrence, convention, and exhibition facilities. London, UK: The Architectural Press

Museum Nasional Indonesia. (2013). Laporan kajian tata pamer (perangkat pameran) Museum Nasional.

SNI 03-6572-2001. (2001). Tata cara perancangan sistem ventilasi dan pengkondisian udara pada bangunan gedung,

Sugiyono. (2006). Metode penelitian pendidikan, pendekatan kuantitatif, kualitatif, dan $R \& D$. Bandung: Alfabeta

Suptandar, P. (1995). Pengantar mata kuliah desain interior, : Jakarta: Universitas Trisakti

Svarajati, T. P. (2009, Juni 25). Jangan bangun museum. Kompas.

Walker, J.A. (2010). Desain, sejarah, budaya, sebuah pengantar komprehensif. (Y. A. Piliang. Penerj.). Yogyakarta: Jalasutra. 